\title{
An Investigation on the Effect of STEM Practices on Sixth Grade Students' Academic Achievement, Problem Solving Skills, and Attitudes towards STEM
}

\author{
Müzdelife Kurt ${ }^{1}$, Semra Benzer²* \\ ${ }^{1}$ Education Institute, Gazi University, Turkey \\ ${ }^{2}$ Science Education, Gazi University, Turkey \\ *Corresponding Author. sbenzer@gazi.edu.tr
}

\begin{abstract}
This study aims to identify the effect of STEM practices, integrated into Science courses in $6^{\text {th }}$ grades of middle schools, on students' academic achievement, problem-solving skills, their attitudes towards STEM, and their interest level of STEM fields. The population of the study consists of $6^{\text {th }}$-grade students enrolled in a middles school in the 2018-2019 academic year. During the research, Academic Achievement Test, STEM Attitude Scale, STEM Career Interest Survey, and Problem Solving Inventory were applied to experimental and control groups as pre and post-tests by quasi-experimental research design. In data analysis, a statistics package program was used. Results of the study showed that the Academic Achievement Test scores of experimental groups that received STEM practices were seen to be higher than that of the control group to which the constructivist approach was applied. The difference was observed to be meaningful. Also, when the post-test scores of the STEM Attitude Scale, STEM Career Interest Survey, and Problem Solving Inventory were compared, a meaningful difference was found between the experimental and control group.
\end{abstract}

Keywords Academic Achievement, Attitude, Interest, Problem Solving, STEM

\section{INTRODUCTION}

In this era of fast-developing technology, countries compete with intellectual power rather than physical power and adapt to developing information and technology. The only way to attain this success is education. However, raising individuals who can produce creative solutions and address problems from various viewpoints is only possible with integrating multidisciplinary practices into educational systems (Çevik \& Özgünay, 2018).

In the dynamic process of developing communities, many fields, including economy, science, medicine, social sciences, engineering, mathematics, and finance, comprise of complicated systems (Sabelli, 2006). Different educational approaches have been developed for such operations as data analysis, data conversion, and new data generation (English \& Sriraman, 2010).

In order to utilize new approaches in education, individuals who are keen on science and enjoy lifelong learning, open to innovation, able to solve a problem, productive and enterprising are needed. Known as 21 st- century skills with the created educational settings, critical thinking and problem-solving, collaboration, and across networks and leading by influence, agility and adaptation, capable oral and written communication, accessing and analyzing information, curiosity, and imagination should be taught to students (Wagner, 2008).

The idea of raising a responsible, problem-solver, and an active individual in the process of interpreting information has produced the opinion of organizing the curriculum according to progressivism philosophy (Yildirım \& Altun, 2015). As the world's new educational trend, STEM, consisting of the initials of Science, Technology, Engineering, and Mathematics, is an educational approach that aims to help individuals gain information and skills with an interdisciplinary approach. Another aim of STEM is to raise individuals who can handle the economic power that can offer an advantage in the industrialization of countries and to transform

Received: 23 November 2019

Revised: 25 February 2020

Published: 17 March 2020 
countries into economically and industrially developed countries (Çevik \& Özgünay 2018). Besides, increasing the number of students who study STEM fields and wish to pursue their professional life in these fields and raising STEM literate individuals are among the targets of this approach (NRC, 2011).

STEM education provided in educational environments promotes interdisciplinary information and skills for life. It prepares individuals for an informationbased economy (NRC 2011). The general purpose of STEM education is to advance future generations with an innovative approach (Çorlu, Capraro, \& Capraro, 2014). In the STEM approach, the practice setting is arranged as it is in real life. Students gain experience in these settings with problem-solving and project-based learning methods by pretending as real engineers, scientists, and technologists (Breiner, Harkness, Johnson, \& Koehler, 2012).

In today's world, where information and technology are rapidly developing, one of the skills known as "21stcentury skills", defined by P21, is the problem-solving skill (P21, 2018). Apart from being an integrated approach, STEM education is essential for individuals to develop 21st-century skills (Yildırm \& Altun, 2015). Students who gain problem-solving skills can produce new information and improve reasoning skills and creativity (Abdullah, Halim \& Zakaria, 2014).

In order for individuals to develop interest and attitude towards science and mathematics, they need to know the concepts related to these fields and interpret science and mathematics. The reason why students do not have any positive or negative attitude towards engineering is that their engineering achievements are not included in the primary and secondary school curriculum (Yllmaz, Yiğit-Koyunkaya, Güler, \& Güzey, 2017). If individuals are asked to pursue a career in STEM, the interest and attitude towards STEM should be changed positively (Moore \& Richards, 2012). Technology and engineering, which enables the application of science and mathematics in our lives, spread to all areas of daily life and offers solutions to the problems of all times of humanity (NRC, 2012). There is also a relationship between variables of interest and attitude and academic achievement. For this reason, the academic success of students will be examined in this research.

National and international studies conducted in primary education level are mostly conducted with 5 th, 7th, and 8th grades (Elliott, Oty, McArthur, \& Clark, 2001; Robinson, 2005; Riskowski, Todd, Wee, Dark, \& Harbor, 2009; Schnittka \& Bell, 2011; Olivarez, 2012; Wyss, Heulskamp, \& Siebert, 2012; King \& English, 2016; Christensen \& Knezek, 2017). When studies on STEM practices are analyzed, no study jointly investigating variables of problem-solving, attitude towards STEM, and interest for STEM fields are not found. Thus, this study is believed to contribute to the literature.

In this study, the aim is to investigate the effect of STEM practices on 6th-grade students' academic achievement, problem-solving skills, their attitudes towards STEM, and to identify their interest level for STEM fields. It will be determined whether there is a statistically significant difference between the academic achievements of the control and experimental group students, their problemsolving skills, their attitudes towards STEM, and their interest in STEM areas before and after the study.

\section{METHOD}

\subsection{Research Model}

In this study, the pretest posttest-controlled group design was employed as a quasi-experimental research design. (Büyüköztürk, Çakmak, Akgün, Karadeniz, \& Demirel, 2016). The Independent variable of pretest posttest-controlled group design is STEM practices; dependent variables are students' problem-solving skills, their interest in STEM fields, their attitudes towards STEM practices, and their academic achievement. In this regard, Academic Achievement Test (AAT), STEM Attitude Scale (SAC), STEM Career Interest Survey (STEM-CIS), and Problem Solving Inventory (PSI) were applied as pre and posttests. The research design of the study is presented in Table 1.

\subsection{Study Consists}

The population of the study consists of 6th-grade students enrolled in a middle school in the central district of Çankırı province in Turkey. Table 2 shows the distribution of students according to gender.

Table 1 Research design

\begin{tabular}{|c|c|c|c|}
\hline Group & $\begin{array}{l}\text { Learning } \\
\text { Model }\end{array}$ & Pre-tests & Post-tests \\
\hline Control & Constructivist & AAT, & AAT, SAC, \\
\hline Group & Approach & $\begin{array}{l}\text { SAC, PSI, } \\
\text { STEM-CIS }\end{array}$ & $\begin{array}{l}\text { PSI, STEM- } \\
\text { CIS }\end{array}$ \\
\hline Experimental & STEM & AAT, & AAT, SAC, \\
\hline Group & Approach & $\begin{array}{l}\text { SAC, PSI, } \\
\text { STEM-CIS }\end{array}$ & $\begin{array}{l}\text { PSI, STEM- } \\
\text { CIS, } \\
\text { Interview } \\
\text { Form }\end{array}$ \\
\hline
\end{tabular}

Table 2 Descriptive statistics results for students in experimental and control groups in terms of gender

\begin{tabular}{llllll}
\hline \multirow{2}{*}{ Group } & \multicolumn{3}{l}{ Gender } & \multicolumn{3}{l}{ Male } & Total \\
\cline { 2 - 6 } & \multicolumn{2}{l}{ Female } & N & $\%$ & \\
Control Group & 7 & 54.00 & 6 & 46.00 & 13 \\
Experimental Group & 10 & 76.92 & 3 & 23.08 & 13 \\
Total & 17 & 65.38 & 9 & 34.61 & 26
\end{tabular}


Table 3 Item analyses of AAT pre-test form for the unit of electrical conduction

\begin{tabular}{llllll}
\hline $\begin{array}{l}\text { Item } \\
\mathbf{N o}\end{array}$ & $\begin{array}{l}\text { Diffi- } \\
\text { culty } \\
\text { index } \\
\left.\mathbf{( P}_{\mathbf{j}}\right)\end{array}$ & $\begin{array}{l}\text { Discrimi- } \\
\text { nation } \\
\text { index }\left(\mathbf{r}_{\mathbf{j} \mathbf{x}}\right)\end{array}$ & $\begin{array}{l}\text { Item } \\
\mathbf{N o}\end{array}$ & $\begin{array}{l}\text { Diffi- } \\
\text { culty } \\
\text { index } \\
\left.\mathbf{( P}_{\mathbf{j}}\right)\end{array}$ & $\begin{array}{l}\text { Discrimi- } \\
\text { nation } \\
\text { index }\left(\mathbf{r}_{\mathbf{j} \mathbf{x}}\right)\end{array}$ \\
\hline 1 & 0.51 & 0.66 & 16 & 0.93 & $0.18^{* *}$ \\
2 & 0.64 & 0.56 & 17 & 0.93 & $0.13^{* *}$ \\
3 & 0.65 & 0.51 & 18 & 0.82 & 0.51 \\
4 & 0.68 & 0.61 & 19 & 0.40 & $0.00^{* *}$ \\
5 & 0.63 & 0.63 & 20 & 0.28 & 0.63 \\
6 & 0.64 & 0.48 & 21 & 0.60 & 0.48 \\
7 & 0.07 & 0.68 & 22 & 0.28 & 0.71 \\
8 & 0.53 & 0.58 & 23 & 0.23 & 0.30 \\
9 & 0.74 & 0.43 & 24 & 0.82 & 0.38 \\
10 & 0.64 & 0.48 & 25 & 0.76 & 0.48 \\
11 & 0.60 & 0.53 & 26 & 0.42 & 0.73 \\
12 & 0.50 & 0.46 & 27 & 0.61 & 0.76 \\
13 & 0.74 & 0.56 & 28 & 0.45 & 0.76 \\
14 & 0.39 & 0.63 & 29 & 0.18 & 0.38 \\
15 & 0.80 & 0.33 & & & \\
\hline
\end{tabular}

**Note: Excluded items are shown as bold and with **.

\subsection{Data Collection Tool}

\section{Academic Achievement Test (AAT)}

AAT has been developed in this study with the aim of assessing students' academic achievement before and after the application. A pilot study of AAT was conducted with 137 students in the 2018-2019 academic year. The analysis of AAT was performed on a statistics program. Three items with a discrimination index below 0.20 were excluded from the test. Analyses proved that AAT is valid and reliable, and the test consisting of 26 items was employed in the study. Item analyses of AAT are presented in Table 3.

\section{Problem Solving Inventory (PSI)}

Problem Solving Inventory, developed by Heppner \& Peterson (1982) and adapted to Turkish by Şahin, Şahin, \& Heppner (1993), was used in this study.

STEM Attitude Scale (SAC)

STEM Attitude Scale, developed by Faber, Unfried, Wiebe, Corn, Townsend, \& Collins (2013) and adapted to Turkish by Yıldırım \& Selvi (2015), was employed in the study. There are eight questions on "Mathematics", nine questions on "Science", nine questions on "Engineering and Technology", and 11 questions on "21st Century Skills".

\section{STEM Career Interest Survey (STEM-CIS)}

STEM Career Interest Survey developed by Kier, Blanchard, Osborne, \& Albert (2013) and adapted to Turkish by Pekbay (2017) was used in the study. There are nine questions on "Mathematics", nine questions on "Science", nine questions on "Engineering", and nine questions on "Technology".

Table 4 Stages of practices done with the control group

\begin{tabular}{|c|c|c|c|c|}
\hline Subject Area & Topic and Concepts & Let's Experiement! & Interactive activies & $\begin{array}{c}\text { Assessment and } \\
\text { Evaluation }\end{array}$ \\
\hline Conductors and & Conductors & Which Materials & Eba & Subject Assessment Test 1 \\
\hline Non-conductors & $\begin{array}{l}\text { Non-conductors Fields of } \\
\text { Usage for Conductors } \\
\text { and Non-conductors }\end{array}$ & $\begin{array}{l}\text { Conduct Electricity? } \\
\text { Are Water and Air } \\
\text { Conductors? }\end{array}$ & $\begin{array}{l}\text { Morpa Kampus } \\
\text { Okulistik }\end{array}$ & \\
\hline Electrical & Electrical Resistance & Which Makes Light & Eba & Subject Assessment Test 2 \\
\hline Resistance and & Factors Affecting & Brighter? & Morpa Kampüs & Assessment of the Unit \\
\hline Related Factors & Electrical Resistance & $\begin{array}{l}\text { Thick or Thin? } \\
\text { Short or Long? }\end{array}$ & Okulistik & \\
\hline
\end{tabular}

Table 5 Stages of practices done with the experimental group

\begin{tabular}{|c|c|c|c|}
\hline $1^{\text {st }}$ Stage & $2^{\text {nd }}$ Stage & $3^{\text {rd }}$ Stage & $4^{\text {th }}$ Stage \\
\hline $\begin{array}{l}\text { 1. Conductors and Non- } \\
\text { conductors } \\
\text { Angles } \\
\text { Building Electrical Circuit }\end{array}$ & $\begin{array}{l}\text { Presenting the information- } \\
\text { based life problem }\end{array}$ & $\begin{array}{l}\text { Model house design by using } \\
\text { engineering design processes }\end{array}$ & $\begin{array}{l}\text { The relationship between } \\
\text { model house lightning } \\
\text { and electrical conduction }\end{array}$ \\
\hline $\begin{array}{l}\text { 2. Real life usage of electrical } \\
\text { conductance and resistivity } \\
\text { Angles }\end{array}$ & $\begin{array}{l}\text { Presenting the information- } \\
\text { based life problem }\end{array}$ & $\begin{array}{l}\text { Water transfer pump design by } \\
\text { using engineering design } \\
\text { processes }\end{array}$ & Water transfer pump \\
\hline $\begin{array}{l}\text { 4. Angles } \\
\text { Algebra } \\
\text { Real life usage of electrical } \\
\text { conductance and resistivity }\end{array}$ & $\begin{array}{l}\text { Presenting the information- } \\
\text { based life problem }\end{array}$ & $\begin{array}{l}\text { Vacuum cleaner design by using } \\
\text { engineering design processes }\end{array}$ & Vacuum cleaner \\
\hline
\end{tabular}


Stages of Application

The teaching process for the control group, conducted in line with the constructivist approach, lasted eight weeks. The Control group consisting of 13 students, were divided into four groups. Concepts provided in the 6th grade Science coursebook were taught to students, and they were asked to take notes. Experiments in the coursebook were conducted together with the groups. Practices done with the control group are presented in Table 4. Examples from students' activities that have been produced during implementation using the STEM approach in class are shown in Figure 1.

The teaching process for the experimental group, conducted in line with the STEM approach, lasted eight weeks. STEM integration process steps offered by Yllırım \& Selvi (2017) were applied in the study. Practices done with the experimental group are presented in Table 5. These steps are explained as follows:

- Identifying the field: The field where STEM is to be integrated is identified. In this study, the field was chosen as the "Science Course".

- Identifying the Learning Domain: Learning domains within the identified field are chosen. In this study, the learning domain was chosen as "Conductors and Nonconductors" and "Electrical Resistance and Related Factors" presented in the unit called "Electrical Conduction".

- Identifying the Relationship with Disciplines: The relationship between the identified learning domain and mathematics, technology, and engineering disciplines is identified. It is the most important and difficult stage of the STEM integration process. In this study, a connection was established between learning domains of "Conductors and Non-conductors" and "Electrical Resistance and Related Factors" in Science course and "Angles and

Table 6 T-test results regarding pre-test scores of AAT, SAC, PSI, STEM-CIS for control and experimental group students

\begin{tabular}{llcclll}
\hline Group & Scale & $\mathbf{N}$ & $\overline{\mathbf{X}}$ & $\mathbf{S S}$ & $\mathbf{t}$ & $\mathbf{p}$ \\
\hline $\begin{array}{l}\text { Control } \\
\text { Group }\end{array}$ & AAT & 13 & $0, .42$ & 0.03 & -2.941 & 0.060 \\
$\begin{array}{l}\text { Experimental } \\
\text { Group }\end{array}$ & & 13 & 0.46 & 0.11 & & \\
$\begin{array}{l}\text { Control } \\
\text { Group }\end{array}$ & PCI & 13 & 2.81 & 0.46 & -2.678 & 0.052 \\
$\begin{array}{l}\text { Experimental } \\
\text { Group }\end{array}$ & & 13 & 3.79 & 0.22 & & \\
$\begin{array}{l}\text { Control } \\
\text { Group }\end{array}$ & SAC & 13 & 3.01 & 0.32 & -2.954 & 0.064 \\
$\begin{array}{l}\text { Experimental } \\
\text { Group }\end{array}$ & & 13 & 3.33 & 0.21 & & \\
$\begin{array}{l}\text { Control } \\
\text { Group }\end{array}$ & STEM- & 13 & 3.10 & 0.35 & 0.328 & 0.746 \\
$\begin{array}{l}\text { Experimental } \\
\text { Group }\end{array}$ & 13 & 3.16 & 0.52 & & \\
\hline *p $<0.05$ & & & & & & \\
\hline CIS & & & & & &
\end{tabular}

DOI: $10.17509 / j s l . v 3 i 2.21419$

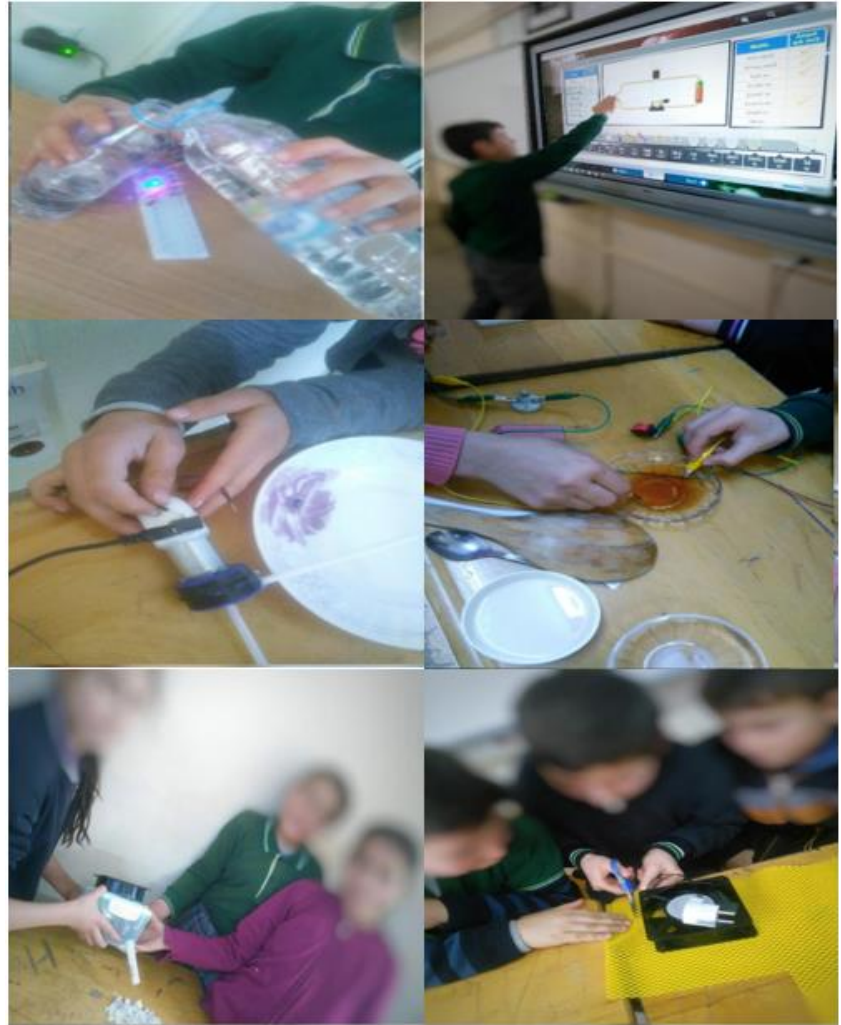

Figure 1 Examples from students' activities of developed in this study

Algebra" learning domains of Mathematics course. As there is no course related to Technology and Engineering in the primary education curriculum, the integration of these domains was provided with combining learning outcomes of Technology and Design course with technology and engineering.

- Designing STEM practices: In this study, four practices appropriate for STEM integration were designed.

- Application: Application and Assessment of Designed STEM Practices (Yildırım \& Selvi, 2017).

\section{RESULT AND DISCUSSION}

Results obtained from the independent samples t-test carried out for determining whether there is a difference among academic achievement, problem-solving skills, attitudes towards STEM, and interest for STEM fields for students in both control and experimental groups before the application are given in Table 6.

There is no meaningful difference among AAT, SAC, PSI, STEM-CIS pretest mean scores of students in the control and experimental group. Thus, it is possible to say that academic achievement, problem-solving skills, attitudes towards STEM, and interest for STEM levels of students in both groups are equal (Table 6). Results obtained from the t-test carried out for determining how academic achievement, problem-solving skills, attitudes towards STEM, and interest for STEM fields for students 
Table 7 Comparative t-test results regarding pre-test and post-test scores of AAT, SAC, PSI, STEM-CIS for control and experimental group students

\begin{tabular}{|c|c|c|c|c|c|c|c|c|}
\hline \multirow{2}{*}{ Groups } & \multirow{2}{*}{ Scale } & \multirow{2}{*}{$\mathbf{N}$} & \multicolumn{2}{|c|}{ Pre-test } & \multicolumn{2}{|c|}{ Post-test } & \multirow[b]{2}{*}{$\mathbf{t}$} & \multirow[b]{2}{*}{$\mathrm{p}$} \\
\hline & & & $\overline{\mathbf{X}}$ & SS & $\overline{\mathbf{X}}$ & SS & & \\
\hline Control Group & AAT & 13 & 0.42 & 0.03 & 0.55 & 0.12 & -4.124 & $0.001 *$ \\
\hline Control Group & PCI & 13 & 2.81 & 0.46 & 3.42 & 0.48 & 4.042 & 0.65 \\
\hline Experimental Group & & 13 & 3.79 & 0.22 & 3.84 & 0.52 & 5.961 & $0.000^{*}$ \\
\hline Control Group & SAC & 13 & 3.01 & 0.32 & 3.21 & 0.84 & -1.178 & 0.261 \\
\hline Control Group & STEM-CIS & 13 & 3.10 & 0.35 & 3.78 & 0.69 & -3.767 & 0.090 \\
\hline Experimental Group & & 13 & 3.16 & 0.52 & 3.82 & 0.72 & -3.532 & $0.004^{*}$ \\
\hline
\end{tabular}

${ }^{*} \mathrm{p}<0.05$

Table 8 Comparative t-test results regarding post-test scores of AAT, SAC, PSI, STEM-CIS for control and experimental group students

\begin{tabular}{|c|c|c|c|c|c|c|}
\hline Group & Scale & $\mathbf{N}$ & $\overline{\mathbf{X}}$ & SS & $\mathbf{t}$ & $\mathrm{p}$ \\
\hline Control Group & AAT & 13 & 0.55 & 0.12 & -2.891 & $0.008^{*}$ \\
\hline Experimental Group & & 13 & 0.71 & 0.15 & & \\
\hline Experimental Group & & 13 & 3.84 & 0.56 & & \\
\hline Control Group & SAC & 13 & 3.21 & 0.84 & -3.446 & $0.002^{*}$ \\
\hline Experimental Group & & 13 & 3.82 & 0.72 & & \\
\hline
\end{tabular}

$*_{\mathrm{p}}<0.05$

in both control and experimental groups differ before and after the application are given in Table 7.

There is a meaningful difference between AAT pretest and posttest mean scores of students in the control group while there is no difference among pretest and posttest mean scores of SAC, PSI, STEM-CIS. A meaningful difference is observed among experimental group students' pretest, and posttest mean scores of AAT, SAC, PSI, STEM-CIS (Table 7). Results obtained from the independent samples t-test carried out for determining whether there is a difference among academic achievement, problem-solving skills, attitudes towards STEM, and interest for STEM fields for students in both control and experimental groups differ after the application is given in Table 8. There is a meaningful difference among AAT, SAC, PSI, STEM-CIS posttest mean scores of students in the control and experimental group (Table 8).

Results obtained from the independent samples t-test carried out for determining how data obtained from the sub-dimensions of SAC and STEM-CIS for students in both control and experimental groups differ before and after the application are given in Table 9. There is no meaningful difference between control group students' pretest and posttest mean scores of SAC sub-dimensions, which are "science", "mathematics", "engineering and technology", and "21st-century skills". While there is a meaningful difference between pretest and posttest mean scores of "science" and "mathematics" sub-dimensions of STEM-CIS, there is no meaningful relationship between pretest and posttest mean scores of "technology" and "engineering" sub-dimensions (Table 9).

Results obtained from the independent samples t-test carried out for determining how data obtained from the sub-dimensions of SAC and STEM-CIS for students in the experimental group differ before and after the application are given in Table 10. There is a meaningful difference between pretest and posttest mean scores of "science", "mathematics", "engineering and technology", and "21st-century skills" of "science" sub-dimensions of SAC. There is no meaningful difference in "science", "mathematics", and "engineering" sub-dimensions of STEM-CIS while there is no meaningful difference in "technology" sub-dimension (Table 10). 
Results obtained from the independent samples t-test carried out for determining whether there is a difference between the sub-dimensions of SAC and STEM-CIS for students in both control and experimental groups after the application are given in Table 11. There is a meaningful difference among posttest mean scores of "science", "mathematics", and "21st-century skills" subdimensions of SAC while there is no meaningful difference in "engineering and technology" subdimension. Also, there is a meaningful difference among posttest mean scores of "science" sub-dimension of STEM-CIS while there is no meaningful relationship in "mathematics", "engineering", and "technology" subdimensions (Table 11).

A meaningful difference was found between AAT pretest and posttest scores of control group students who pursued their science course in its normal procedure. This result indicates that the constructivist approach increases the learning level of students in science courses. An increase was also found in students' learning levels after the application of STEM practices in the experimental group. This shows that STEM practices integrated into science course is effective in increasing students' learning level. In the comparison of control and experimental

Table 9 T-test results regarding pre-test and post-test scores of SAC and STEM-CIS sub-dimensions for control group students

\begin{tabular}{|c|c|c|c|c|c|c|c|}
\hline Scale & Sub-dimension & & $\mathbf{N}$ & $\overline{\mathbf{X}}$ & SS & $\mathbf{t}$ & $\mathrm{p}$ \\
\hline \multirow{6}{*}{ SAC } & Mathematics & Pre-test & 13 & 2.84 & 0.30 & 0.537 & 0.601 \\
\hline & & Post-test & 13 & 2.76 & 0.55 & & \\
\hline & Science & Pre-test & 13 & 2.99 & 0.46 & -1.624 & 0.130 \\
\hline & & Post-test & 13 & 3.23 & 0.76 & & \\
\hline & Engineering and Technology & Pre-test & 13 & 3.00 & 0.42 & -1.205 & 0.251 \\
\hline & & Post-test & 13 & 3.48 & 1.71 & & \\
\hline \multirow{10}{*}{ STEM-CIS } & 21st Century Skills & Pre-test & 13 & 3.18 & 0.55 & -0.450 & 0.661 \\
\hline & & Post-test & 13 & 3.27 & 1.27 & & \\
\hline & Mathematics & Pre-test & 13 & 3.23 & 0.54 & -4.754 & $0.000^{*}$ \\
\hline & & Post-test & 13 & 4.11 & 0.76 & & \\
\hline & Science & Pre-test & 13 & 3.23 & 0.39 & -5.103 & $0.000^{*}$ \\
\hline & & Post-test & 13 & 3.72 & 0.66 & & \\
\hline & Technology & Pre-test & 13 & 3.29 & 0.78 & -2.630 & 0.103 \\
\hline & & Post-test & 13 & 3.91 & 0.87 & & \\
\hline & Engineering & Pre-test & 13 & 2.88 & 0.71 & -3.210 & 0.260 \\
\hline & & Post-test & 13 & 3.38 & 0.95 & & \\
\hline
\end{tabular}

${ }^{*} \mathrm{p}<0.05$

Table 10 T-test results regarding pre-test and post-test scores of the sub-dimensions of AAT, SAC, PSI, STEM-CIS for control and experimental group students

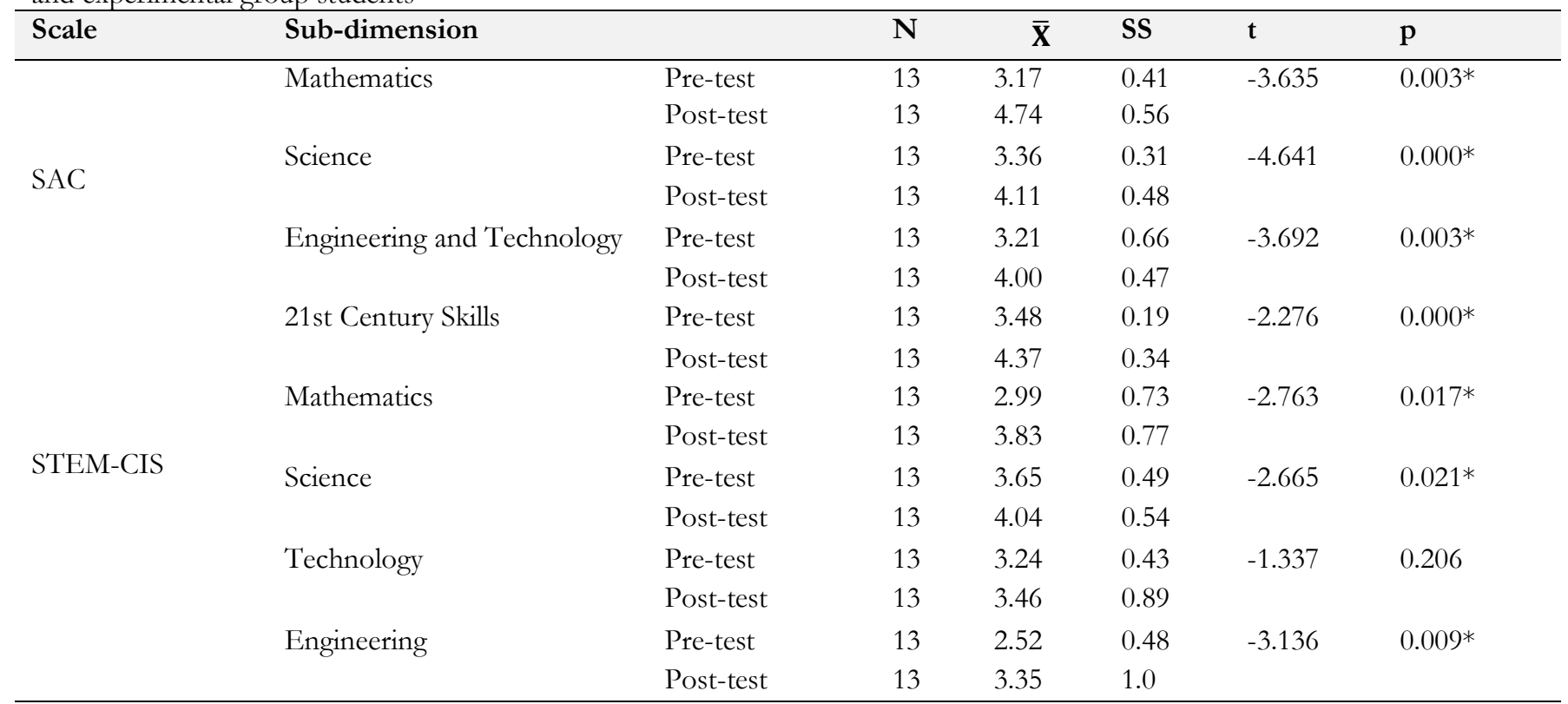

${ }^{*} \mathrm{p}<0.05$ 
Table 11 Comparative t-test results regarding post-test scores of SAC and STEM-CIS sub-dimensions for control and experimental group students

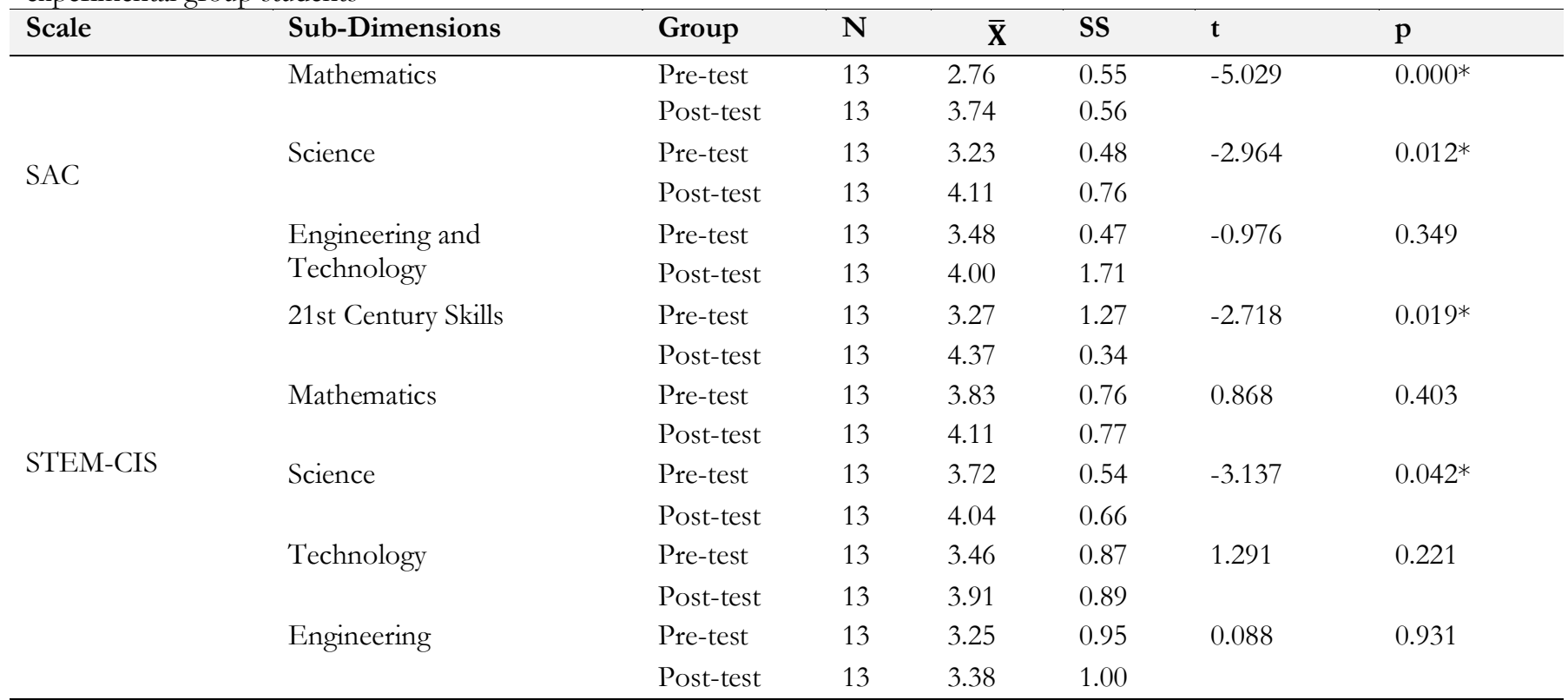

$* \mathrm{p}<0.05$

groups' AAT posttest results, it is seen that there is a meaningful difference in favor of the experimental group. This proves that the STEM integrated science course has a more positive effect on increasing students' learning levels comparing to the constructivist approach. This result is consistent with previous studies showing that STEM practices are effective in increasing students' academic achievement. Marulcu \& Mercan Höbek (2014) investigated the effect of activities they developed with the engineering design method on the academic achievement of 8th-grade students. Their results indicate that the engineering design method has a meaningful effect on students' learning levels. Yılmaz, Gülgün, \& Cağlar (2017) stated that STEM activities they developed for "Power and Energy" unit had a meaningful effect on students' academic achievement and their attitudes towards STEM. In a study by Çevik \& Abdioğlu (2018), it is shown that STEM activities positively increase the academic achievement of 8th-grade students. In another study conducted by İnce, Misır, Küpeli, \& Firat (2018), it was concluded that STEM practices positively affected 5th-grade students' academic achievement and problemsolving skills. Ergün \& Balçın (2019) also found in their single-group pretest and posttest study that problembased STEM practices increased students' academic achievement.

No meaningful difference was found between PSI pretest and posttest scores of control group students who pursued their science course in its normal procedure. This result indicates that the constructivist learning approach has no effect on improving students' problem-solving skills. However, in the experimental group, a meaningful increase was found after STEM-based activities. This may suggest that STEM practices integrated into science courses are effective in improving students' problemsolving skills. When the posttest results of the control and experimental group were compared, a meaningful difference was found in favor of the experimental group. This shows that STEM integrated science course has a more positive effect in improving students' problemsolving skills comparing to the constructivist approach. Results obtained in this study confirm previous studies in the literature. In a doctoral dissertation by Ceylan (2014), the effect of STEM activities on 8th-grade students was investigated. The results of the study showed that STEM activities positively affected students' problem-solving skills. In a study by Şahin, Ayar, \& Adigüzel (2014), the effect of extracurricular STEM activities based on collaboration was investigated, and they were found to improve students' problem-solving skills. Dewaters \& Powers (2006) also found that holistic STEM education improved students' problem-solving skills in real life.

No meaningful difference was observed in attitudes towards STEM in control group students, who were applied constructivist approach, before and after the application. However, in the experimental group provided with STEM practices, a meaningful difference was found in students' attitudes towards STEM before and after the application. This finding suggests that STEM practices integrated into a science course are effective in improving students'attitudes towards STEM. Before and after the application, no meaningful difference was observed in sub-dimensions of attitudes towards STEM, which are "science", "mathematics", "engineering and technology", "21st-century skills" in the control group. However, in the control group where STEM integrated science course was 
conducted, a meaningful difference was observed in subdimensions of attitudes towards STEM which are "science", "mathematics", "engineering and technology", "21st-century skills". A meaningful difference was found in attitudes towards STEM in both control and experimental group students after the application. These results indicate that STEM integrated science course has a more positive effect in improving students' attitudes towards STEM comparing to the constructivist approach. When the literature is reviewed, it is seen that there are studies that have reached similar results. Aydin, Saka, \& Guzey (2017) adapted the STEM attitude scale, developed by Guzey, Harwell, \& Moore (2014), to Turkish and aimed to identify middle school students' attitudes towards STEM. Their results showed that students who have not received STEM education had a moderate level attitude. In a study by Damar, Durmaz, \& Önder (2017), the effect of STEM practices on middle school students' attitudes towards STEM was investigated. According to obtained data, STEM practices were found to increase the attitude towards STEM. Karışan \& Yurdakul (2017) investigated the effect of STEM practices on 6th-grade students' attitudes towards STEM and found a positive change after the study. In a study by Özcan \& Koca (2019), the effect of STEM practices on 7th-grade students' attitudes towards STEM was investigated. Results of the study showed that when academic achievement of control and experimental group were compared, a meaningful difference was observed in favor of the experimental group. Also, practices were seen to improve experimental group students' attitudes towards STEM.

No meaningful difference was observed in interest for STEM in control group students, who were applied constructivist approach, before and after the application. This indicates that the constructivist approach has no meaningful effect on students' interest in STEM. However, in the experimental group, a meaningful difference was found in students' interest in STEM before and after the application. This result shows the meaningful effect of STEM practices on students' interest in STEM. Before and after the application, a meaningful difference was detected in sub-dimensions of interest for STEM, which is "science" and "mathematics" while no meaningful effect was observed in sub-dimensions of "engineering" and "technology" in the control group. This result can be explained by the fact that they receive science and mathematics courses in the primary school curriculum. Before and after the application, a meaningful difference was observed in sub-dimensions of interest for STEM, which are "science", "mathematics" and "engineering"; however, no meaningful difference was seen in sub-dimensions of "technology" in the experimental group. A meaningful difference was found in both the control and experimental group students' interest in STEM after the application. This may suggest that STEM integrated science course has a more positive effect in improving students' interest in STEM comparing to the constructivist approach. Although no previous studies which are in complete agreement with this result have been found in the literature, studies investigating students' interest in STEM fields will be mentioned. Mohr-Schroeder, Jackson, Miller, Walcott, Little, Speler, Schooler, \& Schroeder (2014) aimed to improve 5-8th grade students' interest in STEM in The Blue STEM Camp. After the 5-day camp organized with moderate level students who have a discipline problem in the class, it was seen that their interest and motivation increased, they found the activities fun, and their interest in a career in STEM fields showed a 3\% increase. In a study by Irkıçatal (2016), students' interest in professions in STEM fields was investigated. The results of the study indicated that there was a meaningful difference in "engineering" and "technology" sub-dimensions while no difference was observed in "mathematics" and "science" sub-dimensions. Benek \& Akçay (2018) identified middle school students' opinions on STEM designs. Results of the study conducted with STEM Drawing Form showed that students made use of technology the most and mathematics the least.

\section{CONCLUSION}

This study explores STEM applications on the 6thgrade students' academic success, problem-solving skills, and attitudes towards STEM. The data obtained from AAT, PCI, SAC, and STEM-CIS, which are applied to the control and experimental group students as pre-test and post-test, are evaluated; it can be said that the control group students of PCI "mathematics", "engineering and technology" sub-dimensions have a significant effect on the pre-test mean scores and the "math" sub-dimension general pre-test mean scores. In light of the results obtained in the current study, the following suggestions on STEM practices can be made: First, Turkey's educational system can be organized in accordance with the STEM approach and enhanced with collaboration among university, school, and community. Second, by opening science centers in each city of Turkey, the collaboration of schools with science centers and inservice training for teachers in these centers can be provided. Third, prospective teachers' skills in STEM can be increased by conducting studies on STEM education in the faculties of education. Also, by promoting the collaboration among faculties of education, engineering, and science, prospective teachers can be provided with interdisciplinary STEM education. Fourth, STEM practices can be done starting from pre-school education to higher education without limiting it to one class level only. Fifth, though it can be difficult to integrate STEM into each topic in the curriculum, its effect can be investigated on appropriate topics by conducting STEM 
practices. Sixth, by providing collaborative in-service training for science and mathematics teachers working in the schools of the Ministry of National Education, engineering education can also be included in this training. Seventh, STEM education can be provided for gifted students at a more advanced level, and their opinions on having a career in STEM fields can be motivated. Eighth, More research on STEM can be made, and awareness of STEM can be increased.

\section{ACKNOWLEDGMENT}

The authors would like to acknowledge the teacher and the students who participated in and made this article possible. The authors would also like to thank the reviewers for their valuable comments. This article is based on the part of the first author's Master's Thesis.

\section{REFERENCES}

Abdullah, N., Halim, L., \& Zakaria, E. (2014). Stops: A thinking strategy and visual representation approach in mathematical word problem solving toward enhancing STEM literacy. Eurasia Journal of Mathematics, Science and Technology Education, 10(3), 165-174.

Aydın, G., Saka, M., \& Guzey, S. (2017). Science, Technology, Engineering, Mathematic (STEM) Attitude Levels in Grades 4 - 8. Mersin University Journal of Faculty of Education, 13(2), 787-802.

Benek, İ. \& Akçay, B. (2018). STEM in The My Imaginary World! Investigation of Student's Drawings in STEM Field. Journal of STEAM Education, 1(2), 79-107.

Breiner, J., Harkness, S., Johnson, C. C., \& Koehler, C. M. (2012). What Is STEM? A discussion about conceptions of STEM in education and partnerships. School Science and Mathematics, 112(1), 3-11.

Büyüköztürk, Ş., Çakmak, E. B., Akgün, Ö. E., Karadeniz, Ş., \& Demirel, F. (2016). Bilimsel Arastrrma Yöntemleri. Ankara: Pegem.

Çevik, M. \& Abdioğlu, C. (2018). An Investigation of the Effects of a Science Camp on the STEM Achievements, Science Motivations and Metacognitive Awareness of 8th Grade Students. Journal of Human ad Social Science Research, 7(5), 304-327.

Çevik, M. \& Özgünay, E. (2018). STEM education through the perspectives of secondary schools' teachers and school administrators in Turkey. Asian Journal of Education and Training, 4(2), 91-101.

Ceylan, S. (2014). A study for preparing an instructional design based on science, technology, engineering and mathematics (STEM) approach on the topic of acids and bases at secondary school science course. Msc Thesis, Uludağ University Institute of Education, Bursa, Turkey. P 279.

Christensen, R. \& Knezek, G. (2017). Relationship of middle school student STEM interest to career intent. Journal of Education in Science, Environment and Health (JESEH), 3(1), 1-13.

Çorlu, M. S., Capraro, R. M., \& Capraro, M. M. (2014). Introducing STEM education: Implications for educating our teachers for the age of innovation. Education and Science, 171(39), 74-85.

Damar, A., Durmaz, C., \& Önder, İ. (2017). Middle School Students' Attitudes towards STEM Applications and Their Opinions about These Applications. Journal of Multidisciplinary Studies in Education, 1(1), 47-65.

Dewaters, J. \& Powers, S. E. (2006). Improving science and energy literacy through project-based K-12 outreach efforts that use energy and environmental themes. Proceedings of the 113th Annual ASEE Conference and Exposition, Chicago, IL.

Elliott, B., Oty, K., McArthur, J., \& Clark, B. (2001). The effect of an interdisciplinary algebra/science course on students" problem solving skills, critical thinking skills and attitudes towards mathematics. International Journal of Mathematical Education in Science and Technology, 32(6), 811-816.

English, L. \& Sriraman, B. (2010). Problem solving for the 21 st century. In Theories of mathematics education. Springer, Berlin, Heidelberg.

Ergün, A. \& Balçın, M. D. (2019). The Effects of Problem-Based STEM Applications on Academic Success. Journal of Limitless Education and Research, 4(1), 40-63.

Faber, M., Unfried, A., Wiebe, E. N., Corn, J., Townsend, L.W., \& Collins, T. L. (2013). Student attitudes toward STEM: the development of upper elementary school and middle/bigh school student surveys. 120 th ASSE Annual Conference \& Exposition. Atlanta.

Guzey, S. S., Harwell, M., \& Moore, T. (2014). Development of an instrument to assess attitudes toward science, technology, engineering, and mathematics (STEM). School Science and Mathematics, 114(6), 271-279.

Heppner, P. P. \& Peterson, C. H. (1982). The development and implications of a personal problem-solving inventory. Journal of Counseling Psychology, 29, 66-75.

Ince, K., Misır, M. E., Küpeli, M. A., \& Firat, A. (2018). Examining the Effect of STEM-Based Approach on The Problem-Solving Ability and Academic Success of Students in Teaching the Enigma of The Earth's Crust Unit of the $5^{\text {th }}$ Grade Life Sciences Course. Journal of STEM Education, 1(1), 64-78.

Irkıçatal, Z. (2016). STEM related after- school program activities and associated outcomes on student's success and on their stem perception and interest. Msc Thesis. Akdeniz University Institute of Education, Antalya, Turkey.

Karıșan, D. \& Yurdakul, Y. (2017). The Effects of Microprocessors Based Science Technology Engineering and Mathematics (STEM) Investigations on $6^{\text {th }}$ Grade Students' Attitudes Towards These Subject Areas. Adnan Menderes University Education Faculty Journal of Education Science, 8(1), 37-52.

Kier, M. W., Blanchard, M. R., Osborne, J. W., \& Albert, J. L. (2013). The development of the STEM career interest survey (STEMCIS). Research in Science Education, 44(3), 461-481.

King, D. \& English, L. D. (2016). Engineering Design in the Primary School: Applying STEM Concepts to Build an Optical Instrument. International Journal of Science Education, 38(18), 27622794.

Marulcu, İ. \& Mercan Höbek, K. (2014). Teaching Alternate Energy Sources to 8th Grades Students by Engineering Design Method. Middle Eastern \& African Journal of Educational Research, 9, 42-58.

Mohr-Schroeder, M. J., Jackson, C., Miller, M., Walcott, B., Little, D. L., Speler, L., Schooler, W., \& Schroeder, D. C. (2014). Developing middle school students' interests in STEM via summer learning experiences: See Blue STEM camp. School Science and Mathematics, 114(6), 291-301.

Moore T. \& Richards L. G. (2012). P-12 Engineering education research and practice. Advances in Engineering Education, 3(2), 1-9.

NRC (National Research Council) (2011). Succesful K-12 STEM Education, Washington, DC: National Academy.

Olivarez, N. (2012). The Impact of a STEM program on academic achievement of eighth grade students in a south texas middle school, Doctoral Thesis, Texas A \& M University, Corpus Christi, Texas.

Özcan, H. \& Koca, E. (2019). The Impact of Teaching the Subject "Pressure" with STEM Approach on the Academic Achievements of the Secondary School 7th Grade Students and Their Attitudes Towards STEM. Education and Science, 44(198), 201-227.

P21 (2018). Partnership for 21st century learning 2015. http:// www.p21.org/storage/documents/P21_framework_0515.pdf

Pekbay, C. (2017). Effects of science technology engineering and mathematics activities on middle school students. PhD Thesis, Hacettepe University, Education Science Institute, Ankara.Turkey.

Riskowski, J. L., Todd, C. D., Wee, B., Dark, M., \& Harbor, J. (2009). Exploring the effectiveness of an interdisciplinary water resources engineering module in an eighth-grade science course. International Journal of Engineering Education, 25(1), 181-195. 
Robinson, M. (2005). Robotics-dricen Activities: Can They Improve Middle School Science Learning? Bulletin of Science, Technology and Society, 25(1), 73-84.

Sabelli, N. H. (2006). Complexity, technology, science, and education. The Journal of the Learning Sciences, 15(1), 5-9.

Şahin, A., Ayar, M. C., \& Adıgüzel, T. (2014). STEM related afterschool program activities and associated outcomes on student learning. Educational Sciences: Theory and Practice, 14(1), 309-322.

Şahin, N., Şahin, N. H., \& Heppner, P. P. (1993). The psychometric properties of the Problem-Solving Inventory. Cognitive Therapy and Research, 17(4), 379-396.

Schnittka, C. \& Bell, R. (2011). Engineering design and conceptual change in science: Addressing thermal energy and heat transfer in eighth grade. International Journal of Science Education, 33(13), 18611887.

Wagner, T. (2008). Rigor redefined. Educational Leadership, 66(2), 20-24.

Wyss, V. L., Heulskamp, D., \& Siebert, C. J. (2012). Increasing middle school student interest in STEM careers with videos of scientists. International Journal of Environmental and Science Education, 7(4), 501522.

Ylldirım, B. \& Altun, Y. (2015). Investigating the Effect of STEM Education and Engineering Applications on Science Laboratory Lectures. El-Cezeri Journal of Science and Engineering, 2(2), 28-40.

Yildırım, B. \& Selvi, M. (2015). Adaptation of STEM attitude scale to Turkish. Turkish Studies-International Periodical for the Languages, Literature and History of Turkish or Turkic, 10(3), 11071120.

Yıldırım, B. \& Selvi, M. (2017). An experimental research on effects of STEM applications and mastery learning. Journal of Theory and Practice in Education, 13(2), 183-210.

Yılmaz, A., Gülgün, C., \& Çağlar, A. (2017). Teaching with STEM applications for 7th class student's unit of" force and energy": let's make a parachute, water jet, catapult, intelligent curtain and hydraulic work machine (bucket machine) activities. Journal of Current Researches on Educational Studies (JoCuRES), 7(1), 97-116.

Yılmaz, H., Yiğit-Koyunkaya, M., Güler, F., \& Güzey, S. (2017). Turkish Adaptation of The Attitudes Toward Science, Technology, Engineering, and Mathematics (STEM) Education Scale. Kastamonu Education Journal, 25(5), 1787-1800. 